\title{
Debatforum: Forkyndelse og formidling - i Grundtvigs prædikener og i dag
}

\author{
Af Anja Stokholm
}

Den vedkommende forkyndelse

Hvad gør vor forkyndelse vedkommende? På hvilken måde sikrer vi, at forkyndelsen fører til opvækkelse og oplivelse af menigheden? Hvordan forkynder vi en nærværende Gud? Det er forståeligt nok sådanne spørgsmål om mødet mellem forkyndelsen og menigheden, der optager mange danske præster og teologer. Og det er sandsynligvis også en af grundene til, at der blandt danske præster er en stor efterspørgsel efter såkaldte redskabs- eller værktøjsbøger til hjælp og brug i præstens møde med sin menighed. I disse bøger kan præsten finde hjælp til netop spørgsmål som: Hvordan skriver jeg en god prædiken eller vielsestale? Hvordan forklares dåbens betydning for dåbsforældrene? Hvordan fanges konfirmandernes interesse? osv., osv. Der er i dag stor optagethed og interesse for det formidlingsmæssige i præstens arbejde - heldigvis, for det udgør unægteligt en meget væsentlig side af præstegerningen.

En bestemt fare synes dog ofte at være forbundet med denne optagethed af det formidlingsmæssige, nemlig at det formidlingsmæssige tager overhånd og bliver til selve sagen. Teologien eller forkyndelsen trænges i baggrunden eller regnes for en selvfølgelighed, der ikke har behov for særlig opmærksomhed. Opmærksomheden rettes derimod primært mod retoriske og formmæssige problemstillinger. Og det på trods af den åbenlyse nødvendighed af at sammentænke og forene de to aspekter. Det pudsige er dog, at en sammentænkning af de to aspekter ofte er mere nærliggende og ligetil, end vi forestiller os. Besinder vi os på vore erfaringer af de umiddelbare sammenhænge, vi som mennesker indgår $i$, og på det nære liv, vi lever, synes det formmæssige problem i forkyndelsen lettere at løse. Den i tiden ofte ensidige fokusering på det rent formmæssige og retoriske aspekt synes netop at være et symptom på, at denne sammenhæng mellem det erfaringsnære og forkyndelsen er nedtonet eller glemt. Et eksempel på, hvordan en sådan sammentænkning kan komme til udfoldelse, skal gives ved at henvise til N. F. S. Grundtvigs tænkning.

\section{Grundtvigs prcedikener}

Den påstand skal her anføres, at man i N. F. S. Grundtvigs prædikener finder et elegant eksempel på, hvordan interessen for det formidlingsmæssige, det vil sige interessen for den vedkommende forkvndelse. og 
det teologiske er sammentænkt - ja direkte forenet. De færreste vil nok ved en hurtig gennemlæsning af Grundtvigs næsten to hundrede år gamle prædikener mene, at det formidlingsmæssige aspekt kan være til gavn og inspiration for den nutidige prædikant. De nye udgivelser af Grundtvigs prædikener synes dog måske netop derfor også at have nogle vanskeligheder ved at finde vej til de danske præstegårde. Alligevel skal det her fastholdes, at disse prædikener også i dag taler til os, den let antikverede sprogdragt til trods, og er en rig kilde til både åndelig opbyggelse og formidlingsmæssig inspiration. Det ene aspekt kan ikke løsrives fra det andet. De to sider betinger hinanden - man kan nærmest sige, at hos Grundtvig er det formidlingsmæssige aspekt en side af teologien, af forkyndelsen. Som eksempel på hvordan dette kommer til udtryk, skal fremhæves en af Grundtvigs prædikener fra 1844, nærmere bestemt prædikenen til 16. søndag efter Trinitatis 1844.

Grundtvig prædiker denne dag over teksten om opvækkelsen af enkens søn af Nain. Den første del af prædikenen er en ivrig forkyndelse af Kristi sejr over døden - en sejr, som Grundtvigs samtid synes at have nedtonet eller direkte afvist $i$ de harmoniseringstendenser, der hørte tiden til. Liv og død ses ikke som absolutte modsætninger. Døden opfattes i vid udstrækning som en naturbestemmelse. Døden er Guds eller naturens bestemmelse med mennesket og i den forstand noget naturligt. Kampen og dualismen mellem liv og død er væk, tilbage bliver monismen. Døden kommer i sidste ende fra Gud. Grundtvig kæmper en indædt kamp mod dette ifølge ham - forfejlede og unaturlige syn på døden. Samtiden har glemt dødens bitterhed og alvor. At samtidens syn på døden er forfejlet viser sig ifølge Grundtvig med tydelighed i tekststykket om opvækkelsen af enkens søn af Nain. Kun Kristus kan give trøst til den efterladte enke. Kun han kan udtale ordene: "græd ikke". Og trøsten er ikke, at døden er en naturlig afslutning på livet, men at her, i Kristus, er dødens overvinder, han der forvandler sorg til glæde og død til liv. Døden er en uforsonlig fjende, Guds og menneskets arvefjende, men Livets fyrste er stærkere og sprænger dødens bånd.

I den sidste del af prædikenen kommer Grundtvig ind på sin forståelse af den kristne triade tro, håb og kærlighed, og det er i særlig grad her, noget af det særegne ved Grundtvigs tænkning viser sig. I sin udfoldelse af triaden henviser Grundtvig til Kristi tre dødeopvækkelser. Beretningen om Jairus, hvor troen er i centrum, beretningen om Lazarus med fokus på håbet og endelig fortællingen om enken af Nain, der ifølge Grundtvig handler om den største af de tre, nemlig kærligheden. Den kærlighed, som aldrig - i modsætning til troen og håbet skal ophøre, fordi Gud selv er kærlighed. Det bemærkelsesværdige ved Grundtvigs prædiken er nu, at den kærlighed, som Grundtvig her lovsynger og priser (som større end både tro og håb!), er den naturlige moderkærlighed, og ikke i første omgang den specifikt kristne 
kærlighed. Ja, han understreger ligefrem, at der hos enken hverken findes det mindste spor af tro på Jesus Kristus eller det mindste spor af håb om trøst fra ham. Hun har kun kærligheden, den naturlige moderkærlighed, til det barn, der ligger på båren - en kærlighed så stærk, at selv døden ikke kan ophæve den. Grundtvig prædiker videre således: "Og dog, fordi hendes Kiærlighed dog paa en Maade var stærkere end Døden, derfor skulde hun paa sin tunge Vei til Graven (...) møde Livets Fyrste, Dødens Overvinder, derfor ynkedes Han inderlig over hende, standsede hendes Taare-Strøm med GuddomsOrdet: græd ikke! og forvandlede hendes Sorg til Glæde (...) Ja, m. V. at Guds Kiærlighed paa sin Viis ligesom Menneskets Kiærlighed paa sin Viis, er stærkere end Døden, det var hvad Faderen i det Hele vilde bevise da Han gav os sin eenbaarne Søn". Grundtvig understreger altså sammenhængen og ligheden mellem den naturlige menneskekærlighed og den guddommelige kærlighed. Det er denne lighed, der knytter Gud og menneske sammen. Det er enkens naturlige moderkærlighed, som åbner hendes hjerte for Kristi kærlighed, så hun "begyndte at elske Ham med den samme inderlige, udødelige Kiærlighed, hvormed hun havde elsket sin eenbaarne Søn, og troede herefter hvert Ord, han sagde, haabede Alt, selv det Utroligste af ham". Grundtvig sammenfatter således:

Her see vi da den store Hemmelighed aabenbaret, hvordan Faderen drager Menneskets Hjerte til Sønnen med Kiærligheds Snore, thi vel maae vi paa Herrens Ord troe, det er saa, selv naar vi ikke see det, men her see vi det klarlig, at hos Enken af Nain var Kiærlighed baade det Første og det Sidste, Troens Kilde, saavelsom Haabets Krone, og der er ingen trøsteligere Tanke for Menneske-Hjertet (...) end den, at Kiærligheden, den naturlige Kiærlighed til vore Nærmeste, naar den kun er saa dyb og inderlig, at selv Døden ei kan overvinde og tilintetgiøre den, at denne Kiærlighed, skiøndt den ei naaer til vort Livs Gud og fattes derfor ogsaa nødvendig den Aand, som giør himmelsk levende og trøster over Døden med det evige Liv, denne Kiærlighed er dog dyrebar i den Himmelske Faders Øine, saa af den skaber Han det Fuldkommenheds Baand, der binder Hjertet til Hans Søn og til Ham Selv evindelig.

Gud drager mennesket til sig via den naturlige kærlighed, som han har skænket mennesket i skabelsen. Fordi mennesket kender til kærligheden fra sit naturlige liv, kan det forstå og modtage Guds overvældende kærlighed i Kristus. Mennesket kan tage imod Guds kærlige henvendelse, fordi det i sit eget liv har erfaring for en lignende kærlighed. I Den christelige Børnelcerdom siger Grundtvig det på den måde, at den naturlige kærlighed er grundlaget for og kilden til al anden kærlighed. Og det kan den ifølge Grundtvig netop være, fordi den er "aldeles eensartet" med den kærlighed, der udgår fra Gud. Den naturlige kærlighed mellem mennesker er af Guds egen kærlighed. 
redskab, Gud selv knytter til ved for at gøre evangeliet forståeligt for os. Grundtvig slutter prædikenen med at påpege, at beretningen om enken af Nain viser os, hvordan kærligheden til det nærværende trods manglende tro og håb knytter os til Vorherre.

Lad os nu vende tilbage til den i indledningen udkastede problemstilling, nemlig spørgsmålet om den vedkommende forkyndelse og forholdet mellem forkyndelse og formidling. Påstanden var, at hos Grundtvig forenes de to aspekter på naturlig vis. Ovenstående gennemgang af Grundtvigs prædiken er blot et af talrige eksempler på, hvordan Grundtvig lader det nærværende liv (i dette tilfælde den naturlige kærlighed) være forbindelseslinjen og forståelseshorisonten for forkyndelsen af det usynlige, fremmede og guddommelige. Gang på gang understreger Grundtvig sammenhængen mellem skabelse og genløsning - en sammenhæng, der gør forkyndelsen forståelig, nærværende og vedkommende. Det er den enkeltes egen erfaring (af kærlighed, af kampen mellem godt og ondt, mellem sandhed og løgn og mellem liv og død) og derved den enkeltes eget konkrete naturlige liv, der i Grundtvigs teologi udgør forståelseshorisonten og baggrunden for forkyndelsen af den treenige Gud. Der er således hos Grundtvig tæt sammenhæng mellem det nærværende og det hinsides, og dermed også mellem det formidlingsmæssige og det forkyndelsesmæssige aspekt. På formelagtig vis udtrykker Grundtvig som bekendt tankegangen således: Menneske først, kristen så!

Grundtvigs prædikener, ja Grundtvigs teologi i det hele taget, skal således anbefales til den, der søger inspiration til både vedkommende formidling og oplivende forkyndelse. Det ene udelukker ikke det andet. Der er tværtimod plads til både sammenhæng og vekselvirkning. 